\title{
The Far Reaching Influence of Early Literacy Education: Six Beginning Teachers Look to Their Own Early Literacy Teachers as Role Models for Their Teaching
}

\author{
MONICA McGLYNN-STEWART \\ George Brown College
}

\begin{abstract}
This qualitative research study examined how the professional practice of six beginning elementary teachers was influenced by their own childhood literacy teachers. Results illustrate that the participants' early literacy experiences varied greatly as did the ways in which those experiences intersected with their teaching practice. The participants all reported modeling their teaching after one or two specific teachers from their own childhoods. Using these role models as guides, the participants focused on teaching students whose needs were similar to their own needs as students. Implications for how teachers are chosen, trained and supported are discussed.
\end{abstract}

She was my first real, real teacher. She had standards and she made me meet them. I think she taught me similar to how my parents treated me. Now as a teacher, many times I've taken the extra time to sit down with kids and say, 'Okay, this is what you need to get', just like she did for me.

(Rachel, second year teacher)

There are many factors that influence the teaching practice of elementary teachers and it may be impossible to completely tease out one factor for analysis. However, research has shown that teachers' beliefs and personal experiences play a significant role in their decision making and practice. Teachers' beliefs about pedagogical issues and about themselves as teachers are ongoing subjects for research (e.g., Lamonte \& Engels, 2010; Snider \& Roehl, 2007) including research on teachers' beliefs about teaching literacy (Maloch, Flint, Eldridge, Harmon, Loven, Fine, Bryant-Shanklin \& Marinez, 2003; Quirk, Unrau, Ragusa, Bowers, Nemerouf \& Leora, 2010; Wilson, 2012). A particularly interesting line of research on teachers' beliefs involves the investigation of beliefs about literacy learning and teaching that arise from teachers' personal habits, abilities and experiences (e.g., Benevides \& Stagg Peterson, 2010; Johnson, 2008; Nathanson, Pruslow \& Levitt, 2008; Sunstein \& Potts, 1998). What has not been as well researched is the degree to which teachers' own experiences as school children influence their teaching, particularly in the area of literacy.

This paper reports on one aspect of a research study that examined how the professional practice of six beginning elementary teachers in Ontario, Canada was influenced by their own early childhood literacy learning. The participants' childhood literacy learning and current literacy teaching were explored to examine the ways in which their early literacy experiences influenced their understanding of themselves as 
literacy teachers, their classroom literacy practices, and their understanding of their students. The participants' early literacy experiences varied greatly as did the ways in which those experiences intersected with their teaching practice. This paper looks specifically at the different ways in which the participants used their own early teachers as role models for their literacy teaching.

The purpose of the study was to explore the following questions:

a. How do beginning teachers draw on their own early literacy experiences as pupils in their work as teachers?

b. In what ways do beginning teachers model themselves after specific teachers from their childhoods in their work as teachers?

Three theoretical perspectives informed the design of this study. The first perspective comes from social constructivist theories (e.g., Dewey, 1938/1997; Vygotsky, 1978) which place a strong emphasis on the history, context and social experiences of individuals. According to this perspective, it is through experiences with others that new knowledge and understanding are constructed. A social constructivist lens was used to examine the literacy learning history and current literacy teaching practices of the participants in the study. The second perspective arises from theories that place teachers' actions and decision making at the heart of curriculum development, implementation and change (Connelly \& Clandinin, 1988, 1998; Darling-Hammond, 2006; Fullan, 2007). Third, according to many educational researchers and theorists, teachers' lives, including their learning experiences as students, their beliefs, attitudes and values are of fundamental importance to the process of teacher education and development (Connelly \& Clandinin, 1996; Feiman-Nemser, 2001; Korthagen, 2004; Munby, Russell \& Martin, 2001).

\section{Literature Review}

The literature reveals that there are several ways in which teachers' lives may impact their teaching practice, including their lives as school children. Whether teachers had negative or positive school experiences, it is important that they examine their attitudes and beliefs that arise from their early relationships with family and teachers. It is particularly important that they critically analyze the understanding of teaching and learning that they formed through observing their early teachers.

In her review of the research literature on teacher retention, Rinke (2008) reports on the personal factors that affect teachers' professional lives, including the affects of race, class, gender, personal characteristics and academic ability. She notes that most of the research is retrospective and does not explore the teachers' decision making processes. She called for a new research direction that would incorporate "teachers own perspectives on their careers" (p. 6). Personal history studies suggest that student teachers use their own experiences as students to generalize when interpreting and making decisions about their own teaching (Carter \& Doyle, 1996). Carter and Doyle recommend that teachers' personal history narratives be given a prominent place in teacher education, because if left unexamined, new teachers are likely to perpetuate conventional practice. Furthermore, Wolf, Fallentine and Hill (2000) argue that in order to respond to the literacy needs of their students, preservice teachers need to examine their own beliefs and 
literacy history. Feimen-Nemser (2001) considers teachers' own schooling and early teaching experience to be far more influential than the typical preservice program. She states, "The typical pre-service program is a weak intervention compared with the influence of teachers' own schooling and on-the-job experience" (p. 1014). This study elicited teachers' perspectives on how their own beliefs and literacy histories are implicated in their literacy teaching practice over their first three years of teaching.

Research illustrates that many teachers have had negative literacy learning experiences in elementary school, have poor attitudes towards reading, and do not engage in much reading for pleasure (Applegate \& Applegate, 2004; Morrison, Jacobs, \& Swinyard, 1999; Nathanson, Pruslow \& Levitt, 2008; Sulentic-Dowell, Beal \& Caprano, 2006). Fortunately, there are some studies (Asselin, 2000; Johnson, 2008; Sunstein \& Potts, 1998) that point to pre-service program initiatives that may help address negative attitudes including having pre-service teaches write their own literacy learning stories, create literacy portfolios, or engage in reading response activities. However, very little has been written about elementary teachers' early literacy stories, either inside or outside of school, or how these early experiences influence their understanding and teaching of literacy. Of the few studies that do address teachers' early literacy learning (Johnson, 2008; Nathanson, Pruslow ${ }_{2} \&$ Levitt, 2008; Sunstein \& Potts, 1998), the focus is on preservice teachers, not practicing teachers.

Knowles (1988) emphasizes the importance of examining the relationships between early childhood learning experiences with family members and teachers, teacher role identity, and classroom actions. Schubert (1991) comments that teachers' narratives are often neglected in studies of teaching practice. His work with teachers examining their life stories revealed that as teachers came to know their own stories, they were able to develop more positive relationships with their students.

One of the early learning experiences that may have an influential role in teachers' practices is their many years as witnesses of their own classroom teachers. This is what Lortie (1975) calls the "apprenticeship of observation" (p. 61). He argues that preservice teachers' many years as students provide them with a type of apprenticeship into the profession in that they have observed and interacted with teachers for many years before entering their teacher preparation programs. Their individual experiences with particular teachers inform their image of teaching. However, because of their perspective as students, they are not privy to teachers' goal setting, preparation, or analysis (Lortie, 1975). Moreover, they do not, "perceive the teacher as someone making choices among teaching strategies" (Lortie, 1975, p. 63). Lortie was concerned that teacher preparation does not do enough to dispel the individual, simplistic, and often traditional notions of teaching with which many new teachers enter the profession (Lortie, 1975). Loughran (2006) exhorts teacher educators to help preservice teachers overcome these limitations by allowing them to "see and hear the pedagogical reasoning that underpins the teaching that they are experiencing" (p. 5). He argues that making the tacit knowledge of teaching explicit (Loughran, 2006, p. 9) is essential if preservice education is to move from "teaching as telling" to "teaching for understanding" (Loughran, 2006, p. 10).

Darling-Hammond (2006) further argues that in addition to their "apprenticeship" experiences in teaching, preservice teachers bring other personal attributes and experiences that may get in the way of learning to teach effectively. Ironically, one of these may be their strong academic ability. It may be more difficult for teachers with a 
history of high academic achievement to support student learning because they have few personal experiences of academic struggle (Darling-Hammond, 2006). Bullough and Gitlin (2001) remind us that preservice teachers, as well as practicing teachers, always filter what they learn through "a set of biographically embedded assumptions, beliefs, or pre-understandings" (p. 223). Bullough and Gitlin (2001) caution that, "Ignoring the past does not make it go away. It lingers, ever present and quietly insistent" (p. 223). Given the impact of teachers' experiences, assumptions, and beliefs on their understanding and practice, it is imperative that more attention be paid to teachers' lives in preservice and in-service teacher education.

\section{Methodology}

This study was designed to explore the perspectives of beginning elementary teachers with respect to the influence of their early personal literacy history on their literacy teaching practice. A qualitative research approach was chosen because it matched the goals of the inquiry. In keeping with Merriam's (1998) elements of qualitative research, I was interested in studying how beginning teachers make sense of their own childhood literacy learning experiences, and how those experiences influence their teaching practice. I sought to understand how the participants constructed their ideas, values, and beliefs about literacy learning and teaching. Since I was seeking to understand this from the participants' perspectives, a qualitative approach was most appropriate.

Multiple case studies, with each of the participants constituting a case, were developed, and then themes were explored across cases. The purpose of case studies in qualitative research, according to Patton (2002), is to "gather comprehensive, systematic, and in-depth information about each case of interest" (p. 447). The data is then organized by specific cases in a way that is in-depth, holistic, and context sensitive. The stories of six beginning elementary teachers each form a case, and the six cases were compared and contrasted. Data was collected through classroom observations, interviews, and document analysis. Each participant was observed while teaching in his or her classroom and interviewed five times over 3 years. My goal was to explore the "big picture" of the teachers' early learning context and their literacy teaching context. In addition, I also explored the details of specific early learning experiences, beliefs about learning and teaching, and specific teaching strategies.

\section{Participants}

The six participants in this study were self-chosen from a group of 22 beginning elementary teachers who were already participants in a larger longitudinal study of literacy teachers. The participants were the first six to respond to an invitation to be part of this study. All teachers were graduates of the same large urban university postbaccalaureate preservice program and were in their first year of elementary classroom teaching in the same large urban centre. The teachers all taught at urban schools which differed in terms of size and the socioeconomic and cultural backgrounds of their neighbourhoods. They were all classroom teachers of grades ranging from Kindergarten to Grade 8. Pseudonyms are used but the gender is correct. 


\section{Data Sources}

Data was collected through 5 semi-structured interviews with each classroom teacher over a three year period, classroom observations, and a review of documents related to literacy teaching and learning (e.g., curriculum documents, teacher resource books, program and lesson plans). The use of these three data collection methods allowed for triangulation of the findings (Merriam, 1998). The participants reviewed their transcripts and case studies and provided feedback to the researcher. These main data sources were supplemented with field notes and frequent emails between the participants and the researcher over the course of the study.

\section{Data Analysis}

Data was analyzed using Grounded Theory (Strauss \& Corbin, 1990). In this study, I read the transcripts of interviews, observation notes, and field notes several times during and after the 3-year period of data collection. Each piece of data was identified by participant, data type, and date. After the first round of interviews and observations, I began a process of "open coding" (Strauss \& Corbin, 1990, p. 61). I began to label events and ideas and then to group these concepts together into categories (Strauss \& Corbin, 1990). For example, I developed and used the open codes "family literacy practices," "transition to school," and "literacy teaching strategies." These emerging categories influenced subsequent rounds of data collection. As the study progressed, I also engaged in "axial coding" (Strauss \& Corbin, 1990, p. 96). Using the analytic principles of constant comparison (Glaser \& Strauss, 1967), I began to make connections between categories, and to develop larger themes. For example, I created the axial codes, "connection between home literacy and school literacy" and "connection between early school experiences and teaching focus." I created a chart for each participant in which I listed the emerging themes and the data that supported those themes. From my analysis, I created a common set of categories for the individual case studies which encompass the main findings in the study.

Following the creation of charts for the data on individual participants, I created another chart in which I compared and contrasted the themes from the six individual case studies. Throughout the data collection and analysis period I continually reviewed the materials for clarification, continuing to add, delete, modify, and establish themes. Finally, I integrated the categories and themes using "selective coding" (Strauss \& Corbin, 1990, p. 116). Straus and Corbin (1990) refer to this stage as formulating a "story line" (p. 119) for the study. An example of a selective code that I used is, "teachers who struggled as students focus on their struggling students as teachers."

\section{Limitations}

This study is small in size and scope, with six participants who attended the same teacher education program and taught in the same city. However, the participants' childhood literacy learning experiences were quite diverse as were the types of schools and neighbourhoods in which they taught. Although I tried to present a balanced view of the data, my own learning and teaching history inevitably influenced the data collection and analysis. 


\section{Findings}

The following tables summarize the findings from the individual case studies. In Table 1 below, the six participants are divided into two groups and their early literacy home literacy experiences, early school experiences, characteristics of chosen role models and their own approach to teaching are briefly outlined.

\section{Table 1}

Summary of Individual Case Studies

\begin{tabular}{|l|l|l|l|l|}
\hline Participants & $\begin{array}{l}\text { Early home } \\
\text { literacy } \\
\text { experiences }\end{array}$ & $\begin{array}{l}\text { Early school } \\
\text { experiences }\end{array}$ & $\begin{array}{l}\text { Early teachers } \\
\text { chosen as role } \\
\text { models }\end{array}$ & $\begin{array}{l}\text { Approach to } \\
\text { literacy teaching }\end{array}$ \\
\hline $\begin{array}{l}\text { Kelly, Mike, and } \\
\text { Darren }\end{array}$ & $\begin{array}{l}\text { A great deal of } \\
\text { school-type } \\
\text { reading, writing, } \\
\text { and speaking } \\
\text { experiences }\end{array}$ & $\begin{array}{l}\text { Enjoyable and } \\
\text { successful literacy } \\
\text { experiences }\end{array}$ & $\begin{array}{l}\text { Offered complex } \\
\text { or integrated } \\
\text { projects that } \\
\text { required higher } \\
\text { level thinking } \\
\text { skills }\end{array}$ & $\begin{array}{l}\text { Focus on creating } \\
\text { engaging literacy } \\
\text { experiences }\end{array}$ \\
\hline $\begin{array}{l}\text { Kendra, Gail, and } \\
\text { Rachel }\end{array}$ & $\begin{array}{l}\text { Fewer school-type } \\
\text { reading, writing, } \\
\text { and speaking } \\
\text { experiences }\end{array}$ & $\begin{array}{l}\text { Stressful and } \\
\text { challenging } \\
\text { literacy } \\
\text { experiences }\end{array}$ & $\begin{array}{l}\text { Offered targeted } \\
\text { activities that } \\
\text { addressed the } \\
\text { learning } \\
\text { challenges of the } \\
\text { participants }\end{array}$ & $\begin{array}{l}\text { Focus on both } \\
\text { engaging } \\
\text { effective literacy } \\
\text { experiences }\end{array}$ \\
& & and \\
& & $\begin{array}{l}\text { Assume that some } \\
\text { students will } \\
\text { struggle and need } \\
\text { targeted teaching } \\
\text { strategies }\end{array}$ \\
\hline
\end{tabular}

Table 2 gives more detail about each of the participants and includes their early literacy experiences at home and in the community, their literacy experiences during elementary school, the grades they taught, their understanding of their roles as literacy teachers and their goals for students, and lastly their literacy teaching approach. 
Table 2

Details of Participants' Early Learning and Teaching

\begin{tabular}{|c|c|c|c|c|c|}
\hline Participant & $\begin{array}{l}\text { Early literacy } \\
\text { experiences at } \\
\text { home and } \\
\text { in the } \\
\text { community } \\
\end{array}$ & $\begin{array}{l}\text { Literacy } \\
\text { experiences } \\
\text { during } \\
\text { elementary } \\
\text { school } \\
\end{array}$ & $\begin{array}{l}\text { Grades taught } \\
\text { in first } 3 \text { years } \\
\text { of practice }\end{array}$ & $\begin{array}{l}\text { Understanding } \\
\text { of role as a } \\
\text { literacy teacher } \\
\text { and goals for } \\
\text { students }\end{array}$ & $\begin{array}{l}\text { Literacy teaching } \\
\text { approach }\end{array}$ \\
\hline Kelly & $\begin{array}{l}\text { Parents are } \\
\text { classroom } \\
\text { teachers } \\
\text { Lots of reading } \\
\text { and writing by } \\
\text { adults and } \\
\text { children } \\
\text { Dramatic play } \\
\text { with sisters } \\
\text { Included in } \\
\text { dinner time } \\
\text { conversation } \\
\text { Regular library } \\
\text { visits }\end{array}$ & $\begin{array}{l}\text { No challenges } \\
\text { academically or } \\
\text { socially } \\
\text { Confidently } \\
\text { reading and } \\
\text { writing by } \\
\text { Grade } 1 \\
\text { Entered a Gifted } \\
\text { program in } \\
\text { Grade } 4 \\
\text { Won a creative } \\
\text { writing award }\end{array}$ & $\begin{array}{l}\text { Grades } 6,7, \\
\text { and } 8 \text { Physical } \\
\text { Education and } \\
\text { Health } \\
\text { Grades } 6 \text { and } 8 \\
\text { Math and } \\
\text { Language }\end{array}$ & $\begin{array}{l}\text { Offer exciting } \\
\text { and engaging } \\
\text { Literacy } \\
\text { experiences } \\
\text { Help students to } \\
\text { feel safe and } \\
\text { secure } \\
\text { academically } \\
\text { Wants students to } \\
\text { be confident } \\
\text { communicators, } \\
\text { particularly orally }\end{array}$ & $\begin{array}{l}\text { Integrate Literacy } \\
\text { throughout the } \\
\text { curriculum } \\
\text { Often does not have a } \\
\text { separate Literacy time } \\
\text { Reads to students } \\
\text { Group discussion of } \\
\text { higher level thinking } \\
\text { questions and "big } \\
\text { ideas" } \\
\text { Little focus on basic } \\
\text { skills, formal } \\
\text { assignments or tests } \\
\text { Informal assessment }\end{array}$ \\
\hline Mike & $\begin{array}{l}\text { Mother is a } \\
\text { school librarian } \\
\text { Lots of reading } \\
\text { and writing by } \\
\text { adults and } \\
\text { children } \\
\text { Grandfather } \\
\text { wrote stories with } \\
\text { grandchildren as } \\
\text { characters } \\
\text { Included in } \\
\text { dinner time } \\
\text { conversation } \\
\text { Regular library } \\
\text { visits } \\
\text { Involved in } \\
\text { community } \\
\text { theatre }\end{array}$ & $\begin{array}{l}\text { No challenges } \\
\text { academically or } \\
\text { socially } \\
\text { Confidently } \\
\text { reading and } \\
\text { writing by } \\
\text { Grade } 1 \\
\text { Switched to an } \\
\text { Arts focused } \\
\text { school in } \\
\text { Grade } 4\end{array}$ & $\begin{array}{l}\text { Combined } \\
\text { Grade } 2 \text { and } 3 \\
\text { class } \\
\text { Combined } \\
\text { Junior and } \\
\text { Senior } \\
\text { Kindergarten }\end{array}$ & $\begin{array}{l}\text { Create an inviting } \\
\text { and encouraging } \\
\text { classroom } \\
\text { atmosphere } \\
\text { Foster a positive } \\
\text { attitude toward } \\
\text { reading and } \\
\text { writing } \\
\text { Wants students to } \\
\text { value reading and } \\
\text { writing }\end{array}$ & $\begin{array}{l}\text { Play-based program } \\
\text { with many "hands- } \\
\text { on" learning } \\
\text { opportunities } \\
\text { Most of the time } \\
\text { spent in active } \\
\text { learning centres } \\
\text { Reads to students } \\
\text { Developmental } \\
\text { approach - children } \\
\text { will learn when they } \\
\text { are ready } \\
\text { Little focus on basic } \\
\text { skills, } \\
\text { paper and pencil } \\
\text { tasks, or tests } \\
\text { Informal assessment } \\
\text { through photographs }\end{array}$ \\
\hline
\end{tabular}




\begin{tabular}{|c|c|c|c|c|c|}
\hline Participant & $\begin{array}{l}\text { Early literacy } \\
\text { experiences at } \\
\text { home and } \\
\text { in the } \\
\text { community } \\
\end{array}$ & $\begin{array}{l}\text { Literacy } \\
\text { experiences } \\
\text { during } \\
\text { elementary } \\
\text { school } \\
\end{array}$ & $\begin{array}{l}\text { Grades taught } \\
\text { in first } 3 \text { years } \\
\text { of practice }\end{array}$ & $\begin{array}{l}\text { Understanding } \\
\text { of role as a } \\
\text { literacy teacher } \\
\text { and goals for } \\
\text { students }\end{array}$ & $\begin{array}{l}\text { Literacy teaching } \\
\text { approach }\end{array}$ \\
\hline Darren & $\begin{array}{l}\text { Both } \\
\text { grandmothers } \\
\text { were teachers } \\
\text { Lots of reading } \\
\text { and writing by } \\
\text { adults and } \\
\text { children } \\
\text { "one room } \\
\text { schoolhouse" } \\
\text { Included in } \\
\text { dinner time } \\
\text { conversation } \\
\text { Included in } \\
\text { mother's weekly } \\
\text { discussion group } \\
\text { Involved in } \\
\text { church and } \\
\text { community music }\end{array}$ & $\begin{array}{l}\text { No challenges } \\
\text { academically or } \\
\text { socially } \\
\text { Confidently } \\
\text { reading and } \\
\text { writing by } \\
\text { Grade } 1\end{array}$ & $\begin{array}{l}\text { All grades } \\
\text { from } \\
\text { Kindergarten } \\
\text { to Grade } 8 \text { as a } \\
\text { long term } \\
\text { occasional or } \\
\text { daily supply } \\
\text { teacher }\end{array}$ & $\begin{array}{l}\text { Engage students } \\
\text { through a } \\
\text { nurturing, } \\
\text { positive } \\
\text { environment } \\
\text { Create passion } \\
\text { and excitement } \\
\text { for reading } \\
\text { Wants students to } \\
\text { feel confident to } \\
\text { take risks with } \\
\text { reading and } \\
\text { writing }\end{array}$ & $\begin{array}{l}\text { Integrate literacy } \\
\text { throughout the } \\
\text { curriculum } \\
\text { Reads to students, } \\
\text { particularly picture } \\
\text { books } \\
\text { Collaborative drama- } \\
\text { based } \\
\text { literacy activities } \\
\text { Basic skills will } \\
\text { develop when } \\
\text { students feel } \\
\text { comfortable } \\
\text { expressing ideas } \\
\text { Informal assessment }\end{array}$ \\
\hline Kendra & $\begin{array}{l}\text { Little reading or } \\
\text { writing by adults } \\
\text { or children } \\
\text { No dinner time } \\
\text { conversations } \\
\text { Did not attend } \\
\text { community } \\
\text { programs } \\
\text { Parents believed } \\
\text { that school would } \\
\text { take care of } \\
\text { literacy learning } \\
\text { Spoke some } \\
\text { English before } \\
\text { school }\end{array}$ & $\begin{array}{l}\text { Difficulty } \\
\text { adjusting to } \\
\text { school routines } \\
\text { and co-operating } \\
\text { with other } \\
\text { students } \\
\text { English } \\
\text { language } \\
\text { learning a } \\
\text { challenge } \\
\text { Higher level } \\
\text { thinking skills } \\
\text { more } \\
\text { challenging than } \\
\text { basic skills }\end{array}$ & $\begin{array}{l}\text { Grade 4, all } \\
\text { subjects other } \\
\text { than French } \\
\text { and Music } \\
\text { Grades } 7 \text { and } 8 \\
\text { English, Math, } \\
\text { and Science }\end{array}$ & $\begin{array}{l}\text { Offer a relaxed, } \\
\text { positive learning } \\
\text { atmosphere } \\
\text { Help students } \\
\text { "find their voice" } \\
\text { Wants students to } \\
\text { contribute and } \\
\text { share their } \\
\text { knowledge and } \\
\text { experiences }\end{array}$ & $\begin{array}{l}\text { Specific focus on } \\
\text { literacy learning and } \\
\text { teaching } \\
\text { Large block of time } \\
\text { for literacy activities } \\
\text { such as literature } \\
\text { circles and Readers' } \\
\text { Theatre } \\
\text { Reads to students } \\
\text { One-on-one reading } \\
\text { and writing } \\
\text { conferences to } \\
\text { monitor and assess } \\
\text { student learning }\end{array}$ \\
\hline
\end{tabular}




\begin{tabular}{|c|c|c|c|c|c|}
\hline Participant & $\begin{array}{l}\text { Early literacy } \\
\text { experiences at } \\
\text { home and } \\
\text { in the } \\
\text { community }\end{array}$ & $\begin{array}{l}\text { Literacy } \\
\text { experiences } \\
\text { during } \\
\text { elementary } \\
\text { school }\end{array}$ & $\begin{array}{l}\text { Grades taught } \\
\text { in first } 3 \text { years } \\
\text { of practice }\end{array}$ & $\begin{array}{l}\text { Understanding } \\
\text { of role as a } \\
\text { literacy teacher } \\
\text { and goals for } \\
\text { students }\end{array}$ & $\begin{array}{l}\text { Literacy teaching } \\
\text { approach }\end{array}$ \\
\hline Gail & $\begin{array}{l}\text { Father read to } \\
\text { himself, mother } \\
\text { not a reader, little } \\
\text { reading to } \\
\text { children } \\
\text { Parents rarely } \\
\text { wrote, but } \\
\text { grandmother was } \\
\text { a regular letter } \\
\text { writer } \\
\text { Little dinner time } \\
\text { conversation } \\
\text { Active in sports } \\
\text { and arts activities } \\
\text { in the community } \\
\text { Parents expected } \\
\text { her to do well in } \\
\text { school }\end{array}$ & 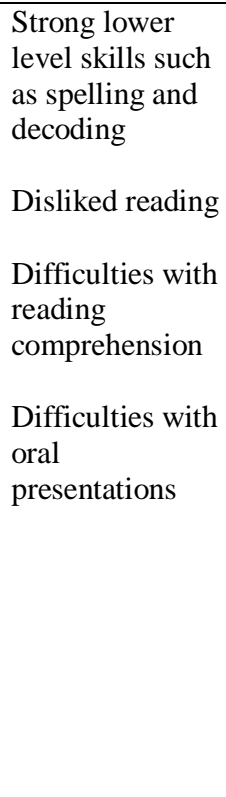 & $\begin{array}{l}\text { Junior and } \\
\text { Senior } \\
\text { Kindergarten }\end{array}$ & $\begin{array}{l}\text { Offers a positive } \\
\text { literacy } \\
\text { environment } \\
\text { Offers a variety } \\
\text { of literacy } \\
\text { resources and } \\
\text { teaching } \\
\text { strategies } \\
\text { Wants students to } \\
\text { enjoy reading and } \\
\text { to have a deep } \\
\text { understanding of } \\
\text { what they read }\end{array}$ & $\begin{array}{l}\text { Specific focus on } \\
\text { literacy learning and } \\
\text { teaching } \\
\text { Large block of time } \\
\text { for literacy activities } \\
\text { that her students } \\
\text { enjoy and can } \\
\text { successfully } \\
\text { accomplish } \\
\text { Reads to students } \\
\text { Regularly tracks } \\
\text { student progress to } \\
\text { ensure that they are } \\
\text { learning }\end{array}$ \\
\hline Rachel & $\begin{array}{l}\text { Grandfather and } \\
\text { uncle were } \\
\text { teachers in Hong } \\
\text { Kong } \\
\text { Parents read to } \\
\text { themselves and to } \\
\text { the children in } \\
\text { English and } \\
\text { Chinese } \\
\text { Parents attempted } \\
\text { to teach her to } \\
\text { read in English } \\
\text { and Chinese } \\
\text { Little dinner time } \\
\text { conversation } \\
\text { Regular library } \\
\text { visits } \\
\text { Studied piano }\end{array}$ & $\begin{array}{l}\text { Difficulty } \\
\text { learning to read } \\
\text { in French, } \\
\text { English, and } \\
\text { Chinese (at } \\
\text { Chinese school) } \\
\text { Frustrated by } \\
\text { learning to read } \\
\text { and "gave up" } \\
\text { Difficulties with } \\
\text { spelling and } \\
\text { organization in } \\
\text { written work } \\
\text { Difficulties with } \\
\text { reading } \\
\text { comprehension }\end{array}$ & $\begin{array}{l}\text { Grade } 4 \text { and } \\
\text { Grade } 5 \\
\text { Extended } \\
\text { French } \\
\text { program (half- } \\
\text { day in English, } \\
\text { half day in } \\
\text { French) }\end{array}$ & $\begin{array}{l}\text { Offers a caring } \\
\text { and welcoming } \\
\text { learning } \\
\text { environment } \\
\text { Focuses on oral } \\
\text { language } \\
\text { development in } \\
\text { French and } \\
\text { writing in English } \\
\text { Wants her } \\
\text { students to have a } \\
\text { positive } \\
\text { experience with } \\
\text { literacy }\end{array}$ & $\begin{array}{l}\text { Integrate Literacy } \\
\text { throughout the } \\
\text { curriculum } \\
\text { More focus on French } \\
\text { literacy } \\
\text { than English literacy } \\
\text { Reads to students } \\
\text { Observes her students } \\
\text { to determine the types } \\
\text { of assistance they } \\
\text { need to improve }\end{array}$ \\
\hline
\end{tabular}


The findings from this study revealed that all of the participants had chosen one or two teachers from among their own early classroom teachers to serve as role models for their literacy teaching. The teachers they employed as role models had a particular characteristic: they had made a positive difference in the learning lives of the participants, particularly of the participants who struggled with literacy learning. The participants report that they purposely employ aspects of their role models' teaching practices, and focus on students who had similar learning needs to the ones that they had as children.

\section{Literacy Teaching was Influenced by One or Two Teachers from their Childhoods}

When asked who their role models were for their teaching practice, all of the participants were able to quickly name one or two teachers from their childhood whom they sought to emulate in their teaching. All participants reported that they employ the practices of former teachers whom they respected, and who provided opportunities for enjoyable and/or successful literacy learning. Gail, Rachel, and Kendra, who struggled with aspects of literacy learning in school, have few memories of positive experiences with literacy teachers upon which to draw. All three of these participants chose to emulate teachers who helped them to see school and themselves differently, and who formed positive relationships with them.

Kelly, Mike, and Darren, who had enjoyable and successful literacy learning experiences throughout their school careers, have many positive memories of literacy learning experiences and role models from which to draw. From their many positive experiences, they chose to follow the example of teachers whose teaching approach was particularly enjoyable and engaging. Kelly's story is representative of the strength and enduring influence of the participants' role models.

Kelly always enjoyed school, had good relationships with her teachers, experienced academic success, and saw herself as capable learner. Kelly chose her most influential teacher from the period of her elementary school life when she switched to a specialized program. Kelly was taught by her role model, Mr. Philips, for both Grades 4 and 5 in a program for students identified as "gifted" learners. Kelly cites Mr. Philips as, "my inspiration as a teacher." She strives to create the same atmosphere, and teaches using some of the same strategies as Mr. Philips. She hopes to inspire her students the way that she was inspired in his class. Kelly remembers her years in his class as fun, challenging, and motivating. She says, "Everything was fun and he challenged us and he read to us - I remember he read The Hobbit in Grade 5, which was great. And we did Art and he brought everyone to their best." Kelly felt challenged but not overwhelmed in his class, "I remember everything was not super hard, but challenging....I remember never being overwhelmed by things."

Just as Mr. Philips did for his students, as a teacher Kelly uses her knowledge of her students' interests to create activities that she hopes her students will enjoy and find motivating. She, too, reads to her students to engage them with literature. Kelly particularly appreciated the integrated projects in Mr. Philips' class. Rather than teaching the subject areas separately, and assessing student learning through simple exercises or tests, Mr. Philips integrated several subject areas in his teaching, including Language and Art, and assigned complex projects. As a student, Kelly found that these projects added interest and excitement to her learning. She says: 
We weren't allowed to get away with something easy and something simple. We'd always have these great projects, nothing was boring. I want to be as great as I remember him being. I want to inspire my kids the way he inspired me.

Kelly had always enjoyed literacy at school, and had been successful in all of her previous teachers' classes, but Mr. Philips offered her opportunities for an increased level of engagement and intellectual challenge. This type of engagement with ideas and intellectual challenge was similar to the way in which Kelly's family engaged with ideas at home. She was well prepared to engage with complex ideas at school, and found the process to be familiar and motivating.

\section{Role Models are Teachers who Made a Difference in their Lives as Children}

As we have seen, Kelly's role model offered her a new level of engagement and enrichment in an already successful and rewarding school career. This was also the case for the other two participants who had had a great deal of school-type literacy at home and successful literacy learning experiences at school, Mike and Darren. Their role models also provided them with a stimulating and motivating environment that they seek to emulate in their teaching.

For the participants who had fewer school-type experiences at home, and who struggled with school literacy learning, their role models made a more profound difference in their early lives. The teachers Gail, Kendra and Rachel chose to emulate initiated a breakthrough in their image of themselves, of school, and of their relationships with teachers. These early role models enabled these participants to see school as relevant, to see themselves as competent literacy learners, and to see teachers as allies. These were all things that they had not experienced previously in their early school years. Gail's story clearly illustrates the difference her role model made in her life, and the reason why she chose to follow her teaching example.

Gail was inspired by her Grade 5 teacher and tries to teach in a similar manner. This teacher, Mrs. Grace, had a different approach to teaching than Gail had encountered before. Mrs. Grace was on a work exchange from Australia and brought with her a set of teaching strategies that Gail found exciting. Up until this point in her school career, Gail had felt bored and disengaged with the individual paper and pencil approach to literacy she had encountered, and was anxious about hiding her comprehension difficulties. Mrs. Grace engaged Gail with her enthusiasm and through hands-on activities that connected the curriculum to real-life issues. One particularly memorable project that Gail recalls from that year was called "The Marriage Project" in which the students pretended to be married couples balancing a budget.

In another innovative project, Mrs. Grace invited Gail and two fellow students to participate in a teacher research project. She highlighted and celebrated Gail's strength in writing by asking her and two friends to participate in a video she was preparing on the writing process that was to be shown to all of the principals in the Board. Being chosen made Gail feel special and also made her feel that her teacher believed in her. She says, "I just remember [Mrs. Grace] having a lot of confidence in me." The real world connection of both of these projects was a motivating factor for Gail. In addition, Mrs. 
Grace gave Gail a position of leadership in her weaker literacy areas. Gail was paired with a new student from Japan who did not speak English, and given the job of helping him with his oral language and reading. Although Gail did not feel that she was a strong reader, or had particularly well-developed oral skills, she was able to help this fellow student. Being put in the position of teacher gave Gail confidence in her own abilities. For the first time Gail felt as if a teacher knew her strengths, needs, and interests, and was able to provide the types of learning activities that motivated and engaged her. Furthermore, Mrs. Grace's confidence that she could succeed in all areas of literacy led Gail to see school, and herself, differently. Gail went from seeing school as a boring place where she needed to pretend to pay attention, to seeing it as a place with engaging activities that she could participate in enthusiastically. Rather than being pre-occupied with hiding her comprehension struggles, Gail began to see herself as a student who was a leader, and who could contribute positively to the classroom.

Like this early role model, Gail makes it a priority in her teaching to be enthusiastic about literacy with her students. She says, "I try to be really, really enthusiastic ...I try to create a really positive environment around literacy in general." Like Mrs. Grace did for her, Gail tries to make literacy fun and meaningful for her students. She gives her students many hands-on opportunities for learning, and ensures that they all have opportunities to be successful. Gail wants her students to feel as she did in Grade 5: confident, competent, and valued.

\section{Literacy Learning Needs as Children Determine the Choice of Role Models}

The participants chose as role models those teachers who met their literacy learning needs as children. As we have seen, Gail, a struggling reader as a child, chose as a role model a teacher who helped her to see the relevance of reading in her life by connecting reading to hands-on activities and real-life issues. Rachel, who had difficulty understanding and following instructions, chose a teacher who gave her the individual attention and specific instruction that she needed. Kendra, an English language learner, chose as her role model the Kindergarten teacher who used music to help her learn English. Kelly, Mike, and Darren, who were highly successful literacy learners, chose teachers who challenged them through discussions of complex ideas, integrated units, and open-ended projects. Mike's case illustrates this theme.

Like Kelly, Mike chose his influential teachers from the first 2 years of a specialized program that he entered at Grade 4. Moving to an Arts-focused school allowed Mike to bring his out-of-school interest in theatre into his school life. Both his Grade 4 teacher, Mrs. Henry, and his Grade 5 teacher, Mr. George, encouraged him to pursue his interests within their literacy programs. Mike engaged in literacy in a personally meaningful and purposeful way by reading and writing theatre scripts and performing in plays. In addition, in this new program he experienced more opportunities for collaborative learning, and for incorporating the Arts into all of the curriculum areas than he had at his previous school. These teachers took the time to get to know Mike's interests outside of school and encouraged him to pursue these interests at school. Moreover, they shared their own interests with the class, and brought their interests into their teaching. Although Mike had been successful with the traditional approach to 
literacy employed by his earlier teachers, he appreciated the newfound opportunities to explore literacy in creative and diverse ways at his new school.

In his teaching Mike tries to incorporate the values and practices that he admired in these two influential teachers: encouraging and sharing personal interests; fostering creativity; and accepting different ideas. As Mike explains:

Those teachers that I remember most fondly are the ones where there was a shared interest. I think that has influenced my practice. I know that was important to me, to feel like they were interested in what I was doing. And their creativity. I try to get some creativity out of [my students] and let them do their thing the way they want to do it. I try to be very accepting of the different ideas that they bring up. That was true of the teachers that I really cared about.

Mike's influential teachers provided an even stronger link between Mike's home and community experiences with literacy and his school literacy learning. In his teaching, Mike sought to recreate this teaching approach that was so enjoyable and motivating for him as a student.

\section{Teachers Focus on Students whose Needs are Similar to their own Needs as Children}

The participants who benefitted from their role models' targeted, individualized instruction, focus on students who have similar needs. Those who benefitted from more open-ended activities that emphasize higher level thinking skills, focus on students who benefit from this approach. Kendra, who belongs to the former group, consciously used her own experiences of struggle to inform her teaching.

From personal experience, Kendra was aware that students can and do struggle with literacy learning, and that teachers need to observe their students closely to determine if they are having any difficulties. She was also aware of what struggling can look and feel like. As a child in Kindergarten, Kendra's frustrations with literacy learning led to some initial behavioural problems in class. Her lack of English fluency made communication difficult and her inexperience with group learning situations made the day-to-day operations of the classroom bewildering. She initially resisted her teacher's directions, and did not want to share or co-operate with the other children. She became able to understand and be understood in conversational English fairly quickly and she acclimatized to the life of the classroom. However, this early experience of schooling left its mark.

Kendra's own experiences as a young English language learner, and as a student who had difficulty following directions and cooperating in group learning activities, has led to her holistic view of learning. She situates each of her student's literacy learning within the wider context of the student's self-concept, peer relations, behaviour, motivation, and general academic ability and performance. She understands from her own experiences that challenges in reading and writing can lead to problems in other subject areas, disruptive behaviour, and difficulty getting along with other students. She believes that students who have literacy challenges are caught in "one of those vicious circles." She explains that what she has observed in her classroom is that when students 
aren't initially successful with literacy, they are reluctant to attempt reading and writing activities. This, in turn, leads to a continued lack of success, which is often followed by a low opinion of themselves and to negative social behaviours. Rather than blaming these students for being reluctant to do their work, or for being disruptive, Kendra sees her job as someone who needs to "light the fire" or find out what will help each student to be successful in their literacy learning so that they can break out of this negative cycle.

For Kendra, seeing and understanding was not enough. She sought to provide the type of teaching strategies, activities, and support that she felt she would have benefited from as a child. She used her own childhood experiences as a reference point when programming for her struggling students. This involves providing engaging opportunities for her junior and intermediate students to integrate their reading, writing, speaking, and listening skills by researching, writing, and orally presenting their opinions on topics of interest.

\section{Discussion}

The findings from this study support much of the research literature in this area. These teachers' beliefs do appear to have influenced their teaching practice and their literacy teaching specifically (Lamonte \& Engels, 2010; Maloch et al., 2003; Quirk et al., 2010; Snider \& Roehl, 2007; Wilson, 2012). Moreover, their personal habits, abilities and experiences played a key role in their choice of teachers to emulate in their own literacy teaching (Benevides \& Stagg Peterson, 2010; Johnson, 2008; Nathanson, Pruslow, \& Levitt, 2008; Sunstein \& Potts, 1998).

As we have seen, all six participants can easily point to one or two teachers from their early schooling who were particularly influential in their learning as students, and who continue to be influential in their teaching. However, there appears to be differences in the role these teachers played when the participants were students, and the role that their memories continue to play in the participants' teaching. For those who struggled with literacy, Kendra, Gail, and Rachel, their role models made a dramatic difference by addressing their area of literacy struggle effectively. They forged a type of positive student/teacher relationship that these participants did not experience elsewhere in their elementary years. In their role models' classrooms, the participants felt that school literacy learning was interesting and made sense. They experienced success, and began to see themselves as capable. They emerged with a new sense of competence and confidence. This gave them a new perception of themselves as literacy learners and hope for their future as literacy students. As teachers, they wish to emulate these role models so that they, too, can make this type of fundamental difference in the lives of their students. They choose to use specific teaching and learning strategies related to their area of struggle that their role models employed and spend a great deal of time on professional development and planning in the area of literacy. While this may benefit their students who struggle in similar ways, a potential negative impact of this approach is that it may leave these teachers with less time to provide their students with enrichment activities.

For Kelly, Mike, and Darren, the teachers after whom they model their teaching do not represent a stark departure from their other elementary teachers. Throughout their elementary years, all three felt that school literacy made sense and that they were capable of being successful at it. They had positive relationships with their teachers, who recognized and celebrated their literacy accomplishments. Rather than providing 
opportunities for these participants to forge a new identity as literacy learners, their role models offered them the opportunity to enhance their already positive and successful experience with literacy learning. Their pre-existing engagement and motivation to learn literacy were heightened by the approaches of these role models. As teachers, these participants seek to engage and motivate their students in the same way. However, not all of their students may have the same skills and experiences that would enable them to benefit from this approach. A potential negative impact of this approach is that their focus on enrichment may allow them less time to pay attention to students who need more targeted teaching strategies.

The beginning teachers in this study report using their own experiences as students as an aid to understanding their students' learning needs. This supports Carter and Doyle's (1996) observation that teachers generalize about students based on their own experiences and also supports Wolf, Fallentine and Hill's (2000) assertion that teachers need to critically examine their own history and beliefs in order to respond to the literacy needs of their students. While all six participants initially assumed that the teaching practices that worked for them as children would work equally well for their students, only the participants who struggled as children experimented to determine if this was true. From their own experiences they knew that not all strategies work for all students. They observed their students closely to determine the extent to which particular strategies and approaches were working for particular children. The participants who experienced success with all the teaching approaches they encountered as students, employed the strategies they enjoyed most, confident that they are equally relevant and enjoyable for all of their own students. As teachers, they approached teaching in a similar way to their role models, in the belief that all of their students will experience the same heightened level of engagement and motivation as they did. When this did not happen for all of their students, they were perplexed.

The findings from this study also challenge some of the assertions in the literature on teacher beliefs and practices. Carter and Doyle (1996) propose that if beginning teachers are not reflective about their own early learning, they are likely to perpetuate conventional practice. This is in spite of graduating from teacher preparation programs that espouse progressive teaching practices. They argue that this is problematic because their students would not be benefitting from current educational theory and recommended practice. The participants in this study were all graduates of teacher preparation programs that advocated progressive approaches to teaching literacy, but as school children they were subject to a range of teaching practices in their school learning lives, from the very traditional to the very progressive. Although none of them employed a completely traditional literacy approach in their classroom, they did plan and implement literacy programs that varied greatly along the continuum. Contrary to Carter and Doyle's (1996) prediction, the participants who reported having the most difficulty meeting students' literacy needs were the ones who were attempting to reproduce the most progressive aspects of their own early learning in gifted and arts-based programs. These participants were perplexed when all of their students did not benefit from their programs in the way that they had as children. However, the participants who employed a range of strategies, including some more traditional ones from which they benefitted as struggling students, reported feeling more success in meeting their students' needs. They appeared to more critically consider which approaches may benefit particular children. The findings from 
the study suggest that it is not the perpetuation of conventional practice that is the problem, but the reproduction of teachers' own early learning experiences in the absence of critical reflection. In the absence of such reflection, even the most progressive strategies may fail some students.

The findings from this study support some aspects of Lortie's (1975) notion of the apprenticeship of observation and challenge others. Lortie argued that preservice teachers' years of observing their teachers when they were students provided them with a type of apprenticeship into the teaching profession. However, as students they were not aware of their teachers' goal setting, planning, student assessment, or analysis of their teaching. In addition, as students they did not "perceive the teacher as someone making choices among teaching strategies" (Lortie, 1975, p. 63). He argued that this leaves many preservice teachers with a simplistic view of teaching. It appears that Kelly, Mike, and Darren may be attempting to reproduce aspects of their role model's teaching approach without fully appreciating their teachers' planning and assessment processes. Because their teachers' approach was appropriate and successful for them, their teachers' deliberate pedagogical choices remained invisible. They were reproducing the aspects of their role models' pedagogy that was visible, such as engaging integrated or arts-focused projects and activities, but without the detailed planning and assessment that happened outside of their view. Darling-Hammond's (2006) caution that those with high academic abilities may face challenges in meeting the needs of struggling learners appears to be supported by this research. The findings from these participants suggest that teachers who were successful literacy students need to engage in more reflection on their early learning to overcome the shortcomings of their apprenticeship of observation.

In contrast, however, Kendra, Gail, and Rachel did not seem to fall prey to the negative effects of the apprenticeship of observation to the same degree. They seem to have a less simplistic view of teaching. As students, they were painfully aware that their teachers were making different pedagogical choices in their literacy program, many of which did not work for them. It may be that the complexity of the literacy learning process is more evident to those who struggled with literacy learning. As teachers, they were more aware that teaching literacy is also a complex process that required them to make appropriate choices among the many teaching strategies available to them in order to meet the needs of all of their students. It may be that teachers who struggled as learners have an 'outsider' perspective that protects them from some of the limitations of the apprenticeship of observation.

\section{Conclusion}

Based on the findings, it is clear that the participants' literacy teaching practices were influenced by significant early childhood teachers. For those who struggled as literacy learners, the teachers they chose to emulate were those who played a significant role in helping to see school and themselves differently, and who formed positive relationships with them. For those who excelled as literacy learners, their chosen role models were those who offered an increased level of engagement and intellectual challenge. Therefore the participants' needs as students influenced the role models they chose in their early teaching career. Furthermore, their perception of their role as literacy teachers, their understanding of student learning, and their teaching and assessment 
practices were all influenced by their experiences in their role models' classrooms and their needs as students. The findings from this study suggest that beginning teachers need to be encouraged and supported to examine the implications of their own literacy learning history to ensure that they are teaching in their students' best interests, rather than from memories of their own experiences.

It is significant that the participants who struggled as literacy learners were more focused on understanding and meeting the needs of diverse learners in their classrooms and on developing as literacy teachers than the participants who excelled in literacy as students. Typically, in pre-service education we look to enroll students who excelled in school, in the belief that because they learned with ease, they are in the best position to teach. This study suggests that perhaps we should be looking beyond academic success in prospective teachers. Having experienced some struggle as a student and having a critical and reflective approach to learning and teaching may at least as important in a teacher candidate as excellence in content knowledge.

The participants in this study, whether they had struggled with literacy learning or not, all appreciated teachers who allowed them to demonstrate their learning in ways that made sense to them. Whether it was being able to learn to speak English through songs in Kindergarten, demonstrating their understanding of a story through role play, or practicing forming letters in the sand table, the participants' most positive and effective early school literacy learning was situated within active learning activities. This finding suggests that teachers need to harness students' interests and preferred learning styles in order to engage students, but also so that they can unveil and acknowledge the learning the students may not yet be able to demonstrate in traditional paper-and-pencil activities. The preservice experiences of the participants in this study illustrate that they were not sufficiently prepared to teach literacy in their elementary classrooms. Having just one literacy course in their program was insufficient. The Kindergarten teachers in this study felt that not enough attention was paid to early literacy learning, and the Junior and Intermediate teachers felt that they were not prepared to teach older students who struggled with literacy learning. Preservice programs must offer more literacy courses that cover the complex field of literacy learning and teaching in a more in-depth way so that beginning teachers begin their career with a full tool box of strategies and an understanding of how and when to use them.

However, a comprehensive understanding of literacy teaching and learning may be insufficient if presevice and beginning teachers haven't been given the opportunity and support to critically examine their own learning history and how it influences their beliefs and attitudes towards teaching and assessment practices, and student learning. The finding of this research suggest that if beginning teachers are not sufficiently reflective about the attitudes and beliefs that arise from their own experiences, they may not be able to serve the best interests of all of their students. This may be particularly true for teachers who excelled as students. Preservice and inservice teacher education must pay more attention to supporting teachers as they reflect on the influence of their own early learning on their teaching. For example, during preservice education, whenever curriculum content or teaching strategies are introduced, teacher candidates could be asked to reflect on what and how they learned as children and how they expect those experiences will influence their teaching. In addition, during the first few years of teaching, inservice workshops could be offered that encouraged beginning teachers to 
examine their teaching in light of their own early learning. The experience of this 3 -year study revealed that asking beginning teachers about their early learning and their teaching provided the opportunity for them to critically examine their learning and teaching and to begin to be more intentional in their decision making and planning processes.

This study is significant because it enriches the literature on teacher beliefs and experiences by exploring how the different literacy learning experiences of beginning teachers can lead them to choose different teachers as role models and different practices to emulate in their own classrooms. By reflecting on how the participants in this study employed literacy teaching practices that had met their needs as students, this research helps us to better understand teachers' literacy pedagogical development. Furthermore, the different levels of reflection and analysis on their early learning and early teaching suggest that teachers who struggled with literacy learning as students may be able to use their experiences and awareness to better understand their students who struggle. For teachers who had an easy time learning literacy, a greater degree of critical reflection on their learning and teaching may be required to meet the needs of their learners, particularly those who struggle with literacy. These findings are significant for teacher education. We need to pay more attention to the early learning lives of our teachers and recognize and support this type of self-reflection during the admission process for teacher candidates, in preservice and in inservice learning. As this study only followed teachers through the first three years of practice, there is a need for more longitudinal research into how teachers' early literacy learning influences their self-image, practice and understanding of student learning throughout their careers.

\section{References}

Applegate, A. J., \& Applegate, M. D. (2004). The Peter Effect: Reading habits and attitudes of preservice teachers. The Reading Teacher, 57, 554-563.

Asselin, M. (2000). Confronting assumptions: Preservice teachers' beliefs about reading and literature. Reading Psychology, 21, 31-55.

Benevides, T., \& Stagg Peterson, S. (2010). Literacy attitudes, habits and achievements of future teachers. Journal of Education for Teaching: International Research and Pedagogy, 36(3), 291-302.

Bullough, R. V., \& Gitlin, A. D. (2001). Becoming a student of teaching: Linking knowledge production and practice. New York, NY: RoutledgeFalmer.

Carter, K., \& Doyle, W. (1996). Personal narrative and life history in learning to teach. In B. Sikula \& R. Geyton (Eds.), Handbook of research in teacher education (pp. 120-142). New York, NY: Simon \& Shuster MacMillan.

Connelly, M. J., \& Clandinin, J. (1988). Teachers as curriculum planners. Toronto, Ontario: OISE Press.

Connelly, M. J., \& Clandinin, J. (1996). Teachers' professional knowledge landscapes: Teacher stories. Educational Researcher, 25(3), 24-30.

Darling-Hammond, L. (2006). Powerful teacher education: Lessons from exemplary programs. San Francisco, CA: Jossey-Bass.

Dewey, J. (1938/1997). Experience and education. New York: Simon \& Schuster.

Feiman-Nemser, S. (2001). From preparation to practice: Designing a continuum to strengthen and sustain teaching. Teachers College Record, 103(6), 1013-1055. 
Fullan, M. (2007). The new meaning of educational change. New York: Teachers College Press.

Glaser, B. G., \& Strauss, A. L. (1967). The discovery of grounded theory: Strategies for qualitative research. New York, NY: Aldine de Gruyter.

Johnson, A. S. (2008). The moral of the story: Agency in preservice teachers' literacy stories. English Education, 40(2), 122-145.

Knowles, J. G, (1988). A beginning teacher's experience: Reflections on becoming a teacher. Language Arts, 65(7), 702-712.

Korthagen, F. (2004). In search of the essence of a good teacher: Towards a more holistic approach in teacher education. Teacher and Teacher Education, 20, 77-97.

Lamonte, C., \& Engels, N. (2010). The development of student teachers' professional identity. European Journal of Teacher Education, 33(1), 3-18.

Lortie, D. (1975). Schoolteacher. Chicago, IL: University of Chicago Press.

Loughran, J. (2006). Developing a pedagogy of teacher education: Understanding teaching and learning about teaching. London: Routledge.

Maloch, B., Flint, A., Eldridge, D., Harmon, J., Loven, R., Fine, J., Bryant-Shanklin, M., \& Martinez. (2003). Understandings, beliefs, and reported decision making of first-year teachers from different reading teacher preparation programs. The Elementary School Journal, 103(5), 431-457.

Merriam, S. (1998). Qualitative research and case study implications in education. San Francisco, CA: Jossey-Bass.

Morrison, T. G., Jacobs, J. S., \& Swinyard, W. R. (1999). Do teachers who read use recommended literacy practices in their classrooms? Reading Research and Instruction, 38, 81-100.

Munby, H., Russell, T., \& Martin, A. (2001). Teachers' knowledge and how it develops. In V. Richardson (Ed.), Handbook of research on teaching ( $4^{\text {th }}$ ed., pp. 877-904). American Educational Research Association.

Nathanson, S., Pruslow, J., \& Levitt, R. (2008). The reading habits and attitudes of inservice and preservice teachers: Results of a questionnaire survey. Journal of Teacher Education, 59(4), 313-322.

Patton, M. Q. (2002). Qualitative research and evaluation methods (3rd ed.). Thousand Oaks, CA: Sage.

Quirk, M., Unrau, N., Ragusa, G., Bowers, E., Nemerouf, A., \& Loera, G. (2010).

Teacher beliefs about reading motivation and their enactments in classrooms: The development of a survey questionnaire. Reading Psychology, 31, 93-120.

Rinke, C. (2008). Understanding teachers' careers: Linking professional life to professional path. Educational Research Review, 3, 1-13.

Schubert, W. H. (1991). Teacher lore: A basis for understanding praxis. In C. Witherell \& N. Noddings (Eds.), Stories lives tell: Narrative and dialogue in education. New York: Teachers College Press.

Snider, V., \& Roehl, R. (2007). Teachers' beliefs about pedagogy and related issues. Psychology in the Schools, 44(8), 873-886.

Strauss, A. L., \& Corbin, J. (1990). Basics of qualitative research: Grounded theory procedures and techniques. Newbury Park, CA: Sage. 
Sulentic-Dowell, M., Beal, G.D., \& Capraro, R. M. (2006). How do literacy experiences affect the teaching propensities of elementary pre-service teachers? Reading Psychology, 27(2-3), 235-255.

Sunstein, B. S., \& Potts, J. P. (1998). Literacy stories extended: Of reflection and teachers' portfolios. Teacher Education Quarterly, 25, 61-72.

Vygotsky, L. S. (1978). Mind in society: The development of higher psychological processes. Cambridge, MA: Harvard University Press.

Wilson, N. (2012). Uncovering teachers' beliefs through the development of a vision statement. American Reading Forum Annual Yearbook [online], 32. Retrieved from http://americanreadingforum.org/yearbook/12_yearbook/documents/Wilson2012.pdf

Wolf, S. A., Fallentine, D., \& Hill, L. A. (2000). “Only connect!” Cross-cultural connections in the reading lives of preservice teachers and children. Journal of Literacy Research, 32(4), 533-569.

\section{Author Biography}

Dr. Monica McGlynn-Stewart is a former elementary teacher, consultant and principal. She now works as a professor in the School of Early Childhood, George Brown College, Toronto, Ontario where she teaches courses in curriculum, early childhood program delivery models, and research methods. She is currently researching beginning elementary teachers' literacy practices and the teaching teams in the new Full-Day Kindergarten program in Ontario. 